\title{
INNOVATIVE APPROACHES FOR ACHIEVING HIGHER QUALITY TRAINING OF FUTURE GEOGRAPHY TEACHERS IN BULGARIA
}

DOI: http://dx.doi.org/10.18509/GBP.2018.66

UDC: 37.011.3-051:91(497.2)

\author{
Georgi Kotseff \\ Tony Traykov \\ Sofia University “St. Kliment Ohridski”, Faculty of Geology and Geography, Sofia, Bulgaria
}

\begin{abstract}
The achieved level of education is one of the fundamental benchmarks defining the social and economic development of a country and the quality of life of its citizens. The training of future teachers (pedagogical staff) is of crucial importance in that matter. The innovation approaches in achieving higher quality training and their application need to be aligned with the current demographic changes and their influence on the labor market. The publication focuses on the process of training geography teachers in the Sofia University "St. Kliment Ohridski" and the application of such innovative approaches that are in line with the contemporary requirements and the needs for high quality geographical didactic education. Research methods: Theoretical analysis, empirical analysis, qualitative and quantitative analysis and evaluation, statistical methods.
\end{abstract}

Key words: Innovative, training, geography, teachers, quality

The education of a population is one of the most significant indicators characterizing the socio-economic development of a country and the quality of life of its population. At the present stage the changing socio-economic environment in Bulgaria sets new requirements for the development of education, meeting the leading standards in the countries of the European Union. At the same time, these requirements must also take into account the demographic and social changes taking place in our country and their impact on the labor market. Improving the quality of educational services can also be seen as a prerequisite for providing the country with well-trained staff in all spheres of public life. The importance of education and skills of human resources is further enhanced in the conditions of globalization and free movement of young people seeking quality education services.

The educational level of the population is the basis of international comparisons for the social progress of countries in different parts of the world. Among the most used for these comparisons are the Human Development Index and the Social Progress Index [1]. In both indices, Bulgaria has improved its position over the past two decades.

The Human Development Index covers three measurable aspects of human development - a long life in good health (measured by life expectancy), education (measured by adult education and school attendance by children) and a good standard of living (measured at the level of income and purchasing power). In 2015 Bulgaria is 59th in the Human Development Index. The better position of the country compared to the previous years is due to the well-known increase in the average life expectancy of 73.6 years, as well as the slight increase of the gross national income per capita. UN data show that $98.4 \%$ of the population over the age of 15 in Bulgaria is literate. The deficiency of the Human 
Development Index can be determined by the fact that it does not give an idea of the educational structure of the population by degrees of education.

Regarding the Social and Environmental Progress Index Bulgaria improves its position two steps ahead in 2017 and ranks 41th among the 128 countries in the world [1]. The report is based on an analysis of the situation in the surveyed countries by the US NGOSocial Progress Imperative. Unlike the Human Development Index, the Social Development Index has more and more diverse compositional indicators used to assess the environmental and social surroundings for the life of the population. They have a total of 12 and are divided into several groups related to the satisfaction of the basic human needs, providing the necessary welfare of the population and opportunities for its development and social inclusion [2]. Two of the indicators reflect the conditions for increasing education - access of the population to basic education and access of the population to higher education. The remaining indicators are related to certain aspects of the state of the surroundings and the social environment, including nutrition and sanitation, housing security, personal safety, health, personal freedom and right of choice. Each of these indicators yields a distinct number of points and determines the location of the country among the remaining 128. Strengths in Bulgaria's presentation in the report include access to housing and higher education, the satisfaction of basic human needs and progress in some aspects of ecology. From the educational conditions' point of view, the differences in access to basic and higher education in the country make an impression. On access to primary education, Bulgaria is ranked 46th, while on access to higher education it is 38th in the world ranking. Bulgaria's achievements in higher education are well above the average in the ranking. The good results coincide with the results of the last census of Population in Bulgaria in 2011 [3]. As of 2011, the number of people with completed higher education is 1348,7 thousand, which means that every fifth (19.6\%) is a graduate. Compared to the previous census in 2001, the relative share of graduates shows an increase of 5.5 points. In addition to broad access to higher education, the reason for the good ranking of Bulgaria is the equal representation of both genders in universities. Data from the last census shows that men's education as a whole is slightly higher than that of women due to the higher relative share of men with secondary and higher education $-63.6 \%$ vs. $62.4 \%$ for women. At the same time, it should be noted that women in Bulgaria graduate from higher education more often than men. For example, at the time of the census graduates are 791.8 thousand women $(22.3 \%$ of the women aged 7 and older) and 556.9 thousand men ( $15.7 \%$ of men aged 7 and older). These favorable results are assessed as a good starting point for improving the quality of labor potential but do not mean that there are no problems in the higher education sector. The report on Bulgaria in the European Commission's 'Education and Training in Europe' survey among the most important tasks of higher education in Bulgaria is the increase in its quality and applicability in the labor market [4]. This necessity is confirmed by the lower employment rate of recent graduates in Bulgaria. In 2016, it is $78.5 \%$ at an average of $82.8 \%$ for EU countries. At the same time, there are discrepancies between the skills and knowledge of young graduates and the requirements of their subsequent employment. The data for our country shows that $35 \%$ of graduates of a Bachelor's degree work in a position that does not require the specified degree. For comparison, the average value of this indicator in the EU is about $25 \%$. Problem is represented by the imbalance established in the last years in Bulgaria in the scientific and professional sectors. In 2015 half of the graduates in Bulgaria have studied social sciences, business management and law with an avarage of $25 \%$ for the EU as a whole. At the same time, the share of graduates in different practice- 
related fields related to the development of medicine, engineering and natural sciences is decreasing, which in the future will exacerbate the problems with the development of important social sectors such as health care, social care, education, etc. [5].

In the context of globalization and increased migratory activity of the population in different parts of the world, the importance of profiled knowledge will become more and more important for the world as a whole as well as for individual countries and regions. The objective of this process is to increase the interest in geographic knowledge as a whole and in its specialized fields related to geographic education. As a positive step for the development of the geographic education in our country we can mention the inclusion of Geography in the priority professional fields, which are financed with priority in the state universities in Bulgaria.

Regarding the preparation of the future pedagogical specialists in our country - geography teachers, the country, in the face of the Ministry of Education and Science, develops an active strategic policy for their quality education. The challenges of our times have, over the years, led to radical and strategic changes in the legal framework outlining the state requirements for acquiring a professional qualification as a teacher, including Geography. By the ordinance adopted in 2017 by a Decree of the Council of Ministers of the Republic of Bulgaria, № 289 in force for the academic year 2017/2018, new rules and conditions for acquiring a teaching capacity will be enforced, which will considerably improve the quality of the training of future teachers [6]. The Ordinance outlines the new accents in this training, fully in line with the modern development of Geographical Education, which is based on the expectation of future teachers with their knowledge, skills and competencies to fully satisfy the expectations of the Bulgarian society and all the educational subjects in it.

During the academic year 2017/2018 at the Sofia University "St. Kliment Ohridski ", in accordance with the requirements of the new normative document, began the training of the first bachelor degree from Geography, History and Geography and Geography and Biology at the Faculty of Geology and Geography. On the basis of the new adopted and already existing curriculum in the faculty [7], a variety of theoretical and practical disciplines are offered, in compliance with the new regulation on the state requirements for acquiring the professional qualification "teacher". Innovations can be analyzed as qualitative - related to the contents of the read courses and practical exercises, and quantitative - on the change in the teaching hours of the disciplines. Several findings can be summarized to clarify the nature of the innovations that imply better education for future Geography teachers.

Teaching is mainly done in two major directions: theoretical training and practical training.

Theoretical training suggests learning in three groups of disciplines: compulsory, elective and facultative.

Compulsory disciplines include the following courses: Pedagogical Psychology; Pedagogy; Methodology of geography education; Inclusive education and project-based training; Information and Communication Technologies in Geography education. It gives an impression of the traditional place with the necessary number of hours in the main courses in Psychology, Pedagogy, and Methodology of Geography Education. They are a serious theoretical basis on which private didactic courses are built in the coming years, more closely related to the Didactics of Geography. Novelty is the compulsory course "Inclusive Education", which is an adequate strategic decision related to the growing number of dropouts from the Bulgarian education system, children with various problems 
and children with special educational needs. The course in audiovisual technologies in education, in line with the development of modern technologies in education, has now been replaced with the course "Information and Communication Technologies in Geography Education", which responds to the increasingly present and necessarily competent approach in Bulgarian education in particular development of digital competence. The minimum hours of academic hours are retained against older normative documents, respectively for the Pedagogy and Psychology courses they are 60 hours; for the course on Methodology of Geography Education - 90 hours; Inclusive Education - 15 hours, and Information and Communication Technologies in Geography Education - 30 Academic Hours.

Elective courses have a course of at least 30 academic hours, meaning they are divided into two groups as follows: First group: pedagogical, psychological and private-didactic, and Second group: interdisciplinary and applied-experimental. To the First group, according to the new curriculum in the Faculty of Geology and Geography, the following disciplines are offered: Methodology and Methodology of Pedagogical Studies, Control and Diagnostics of Results in Geography Education, Rhetoric and Applied Psychology. The Second group of disciplines refers to: History of Geographical Discoveries, Landscape Geography of Bulgaria, Regional Geography of the European Union, Ecological Hydrology and Renewable Energy Resources. It is noteworthy that both groups are closely related both to the traditions of geographic didactic education in Bulgaria (first group) and to contemporary problems, the study of which will give a clearer idea to future teachers of global themes needed in teaching the subject Geography at school. Trained bachelors must choose a minimum of two disciplines from each group according to their personal interests.

Optional learning subjects broaden students' knowledge in several areas: History of Geography Education and Modern Geography Education Models.

The second major direction in the preparation of future geography teachers is related to their practical training. The training is intended to be related to the Hospice, Current pedagogic practice and Internship practice. Teacher training is closely linked to the observation and analysis of pedagogical situations, geography lessons and other forms of school education. The discipline exists traditionally and is the practical expression of the training of the students in the theoretical course on Geography training. The other two practices - current and internship - are also traditional in the preparation of future teachers. It is noticeable that the hours for practical classes are increased according to the new normative documentation. If for Pedagogical Practice up to 45 hours were spent a year ago, now they are 60 hours, and for trainees, if they were 75 hours, they are now 90 hours. This decision, reflected in the new Ordinance on acquiring a professional geography teacher, is, in our opinion, adequate, as on the basis of more practical activities within the framework of the practices, students gain more experience, confidence and self-esteem, observing the greater variety of pedagogical situations in school, preparation and delivery of different types of lessons and development of different pedagogical forms of learning [7].

The new normative documentation can be accepted as a good basis and approach on which could be built a better education and academic education of the future teachers of geography in Bulgaria. The strategic decision for qualitative meaningful change, the preparation of new lecture courses and the traditional retention of old courses, as well as the decision to increase the time for practical preparation of the students preparing for teachers is in line with the state policy, the expectations of the society towards the 
geographic education and the new trends in the development of the Didactics of Geography in Bulgaria.

\section{REFERENCES}

[1] Игнатова, Л. България подобрява позицията си в класация за социален прогрес. Вестник Капитал, 22.06.2017

[2] Владимирова, К. Населението на България и неговите структури. Business Club, Бр.11, 2017

[3] Преброяване на населението и жилищния фонд в България през 2011г. Демографски и социални характеристики на населението. НСИ, С.,2011

[4] Обзор на Европейската комисия „Образование и обучение в Европа” Сп. Business Claub, Бр. 11, 2017

[5] Атанасов, А., Здр. Тонева, М. Белчева, Коцева, Т. и др. Населението на България в началото на XXI век - състояние и тенденции. Акад. изд.”Проф. М. Дринов”, С., 2011

[6] Наредба за държавните изисквания за придобиване на професионална квалификация „Учител”. ПМС № 289 от 7.11.2016г., дбн., ДВ, бр. 89 от 11.11.2016г.р в сила от учебната 2017/2018

[7] Учебен план на Професионално направление Науки за Земята, Геолого-географски факултет, Специалност География, бакалавърска степен, утвърден от Академичния съвет на СУ „Св. Климент Охридски” на 25 Октомври 2017 